\title{
Practical Results of Telemedicine System Between Antarctic Station and Japan
}

\author{
Giichiro Ohno \\ National Institute of Polar Research, Tokyo \\ Department of Surgery, Tokatsu Hospital, Chiba \\ Japan
}

\section{Introduction}

It is as sure as ice is ice that being a medical doctor is a rewarding job. A good surgeon starts and ends the day to save many precious lives in the operating room with the most powerful team. Though he is satisfied with his role, the doctor notices one day that he does not know whether it is raining or sunny outside, or even what the season is now. At that time, it creeps into his heart that he wants to work by himself with a daily awareness of nature in every respect, for instance as a doctor in Antarctica.

He tries working in Antarctica to find unexpected extreme medicine waiting for him.

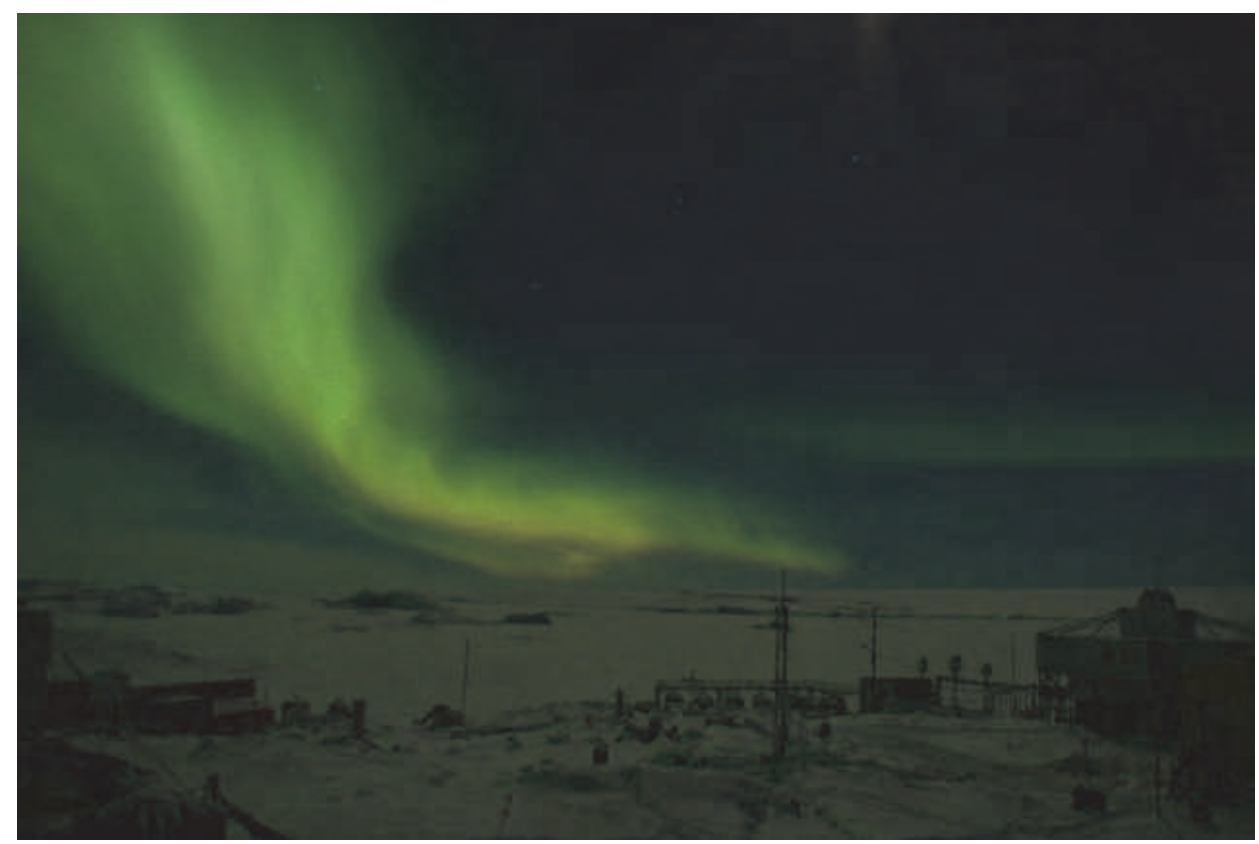

Photo by Toyama Y. 


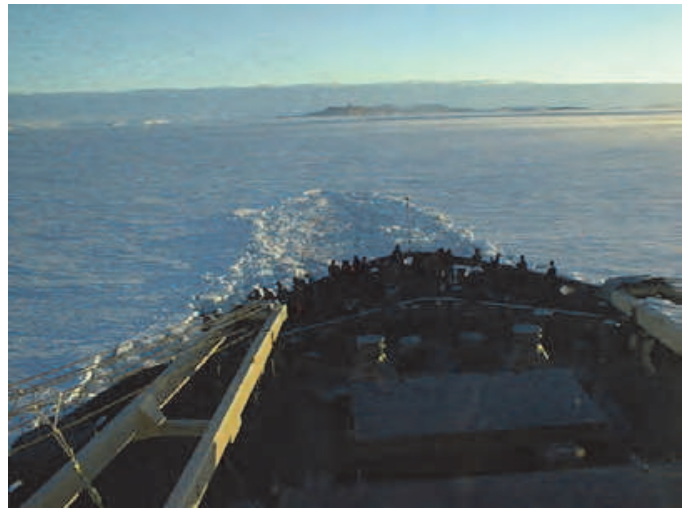

\section{Antarctic research tells us about tomorrow's earth and space}

The Japanese Antarctic Research Expedition (JARE) has had a continued presence in Antarctica, and has continued the survey with winter-over operation since 1956 at Syowa station $\left(\mathrm{S} 69^{\circ}, \mathrm{E} 39^{\circ}\right)$

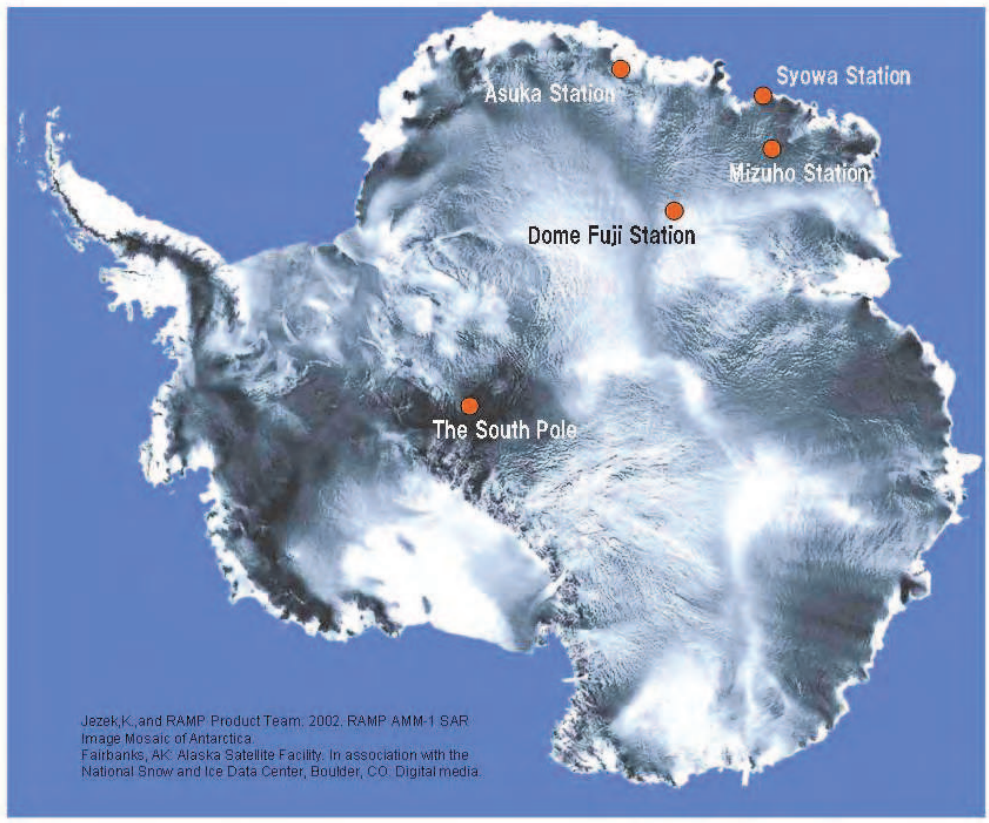

At the dawning of the expedition, it was a life-risking enterprise for its own sake to spend a winter in such an unapproachable and potentially hostile environment. After setting up the station and refining operational methods, energetic researches were made to clarify the last unexplored area including the mysterious aurora, many unique forms of life, climatic conditions and meteorology, the nature of the huge ice cap covering the continent $2000 \mathrm{~m}$ in thickness and the continent itself concealed beneath. These riddles continue to attract many 
researchers to this day. Recently Antarctica has been noticed afresh. The location, isolated and far from civilized society makes Antarctica the most sensitive monitor of climate change and its cooling system is the key of the earth warming. The Ozone layer shows Antarctica as a forerunner of world environmental disruption. It becomes clear that the Aurora influenced by solar wind and Antarctic meteorites teach us about solar system and earth. The Antarctic continent has a large part to play in understanding plate tectonics. Antarctic research expeditions have been going on for a half century history and will continue.

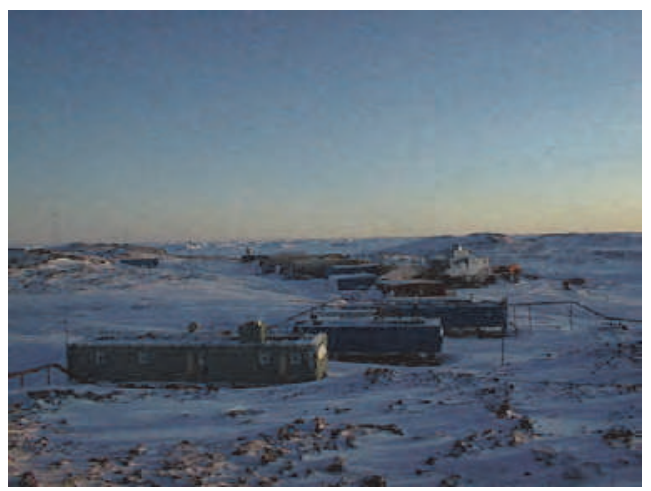

Syowa Station

\section{Complete isolation in icebound Antarctica}

It is a particular luxury to appreciate extreme nature through the window from a warm comfortable room. The Japanese Antarctic station has been repaired every year and updated with the latest technology so that participants are able to stay not only without the dangers of the past but also with a comforts of home. But once they step out of the door, the ferocity of nature is still there, yet many outdoor operations and field investigations are managed. It is even impossible to go the next building just in the station area without a degree of danger. The sole victim of Japanese expedition over the years, was lost when he attempted to go the doghouse from main building within the base area.

Hours of monthly sunlight at Syowa Station

(average of 1971-2000)

Japan Meteorological Agency

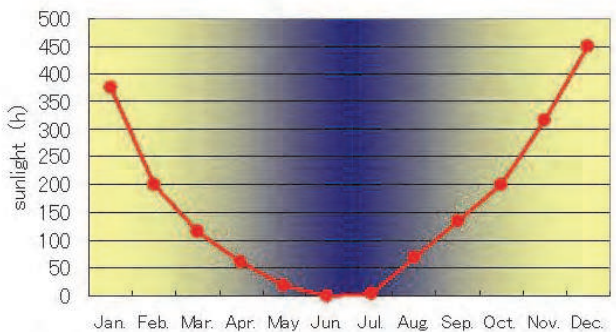

Temperature at Syowa Station

(average of 1971-2000)

Japan Meteorological Agency

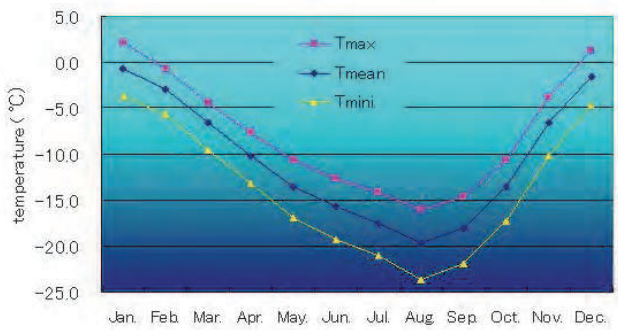


Syowa station is a coastal one and the temperature is $-5^{\circ} \mathrm{C}$ in summer and $-40^{\circ} \mathrm{C}$ in winter. The Antarctic continent is covered by a thick ice sheet that has an average thickness of over two thousand meters. The temperature becomes drastically lower inland on the ice sheet. Dome Fuji, one of Japanese Antarctic bases is S $77^{\circ}$, E39 $9^{\circ}$ and 3810 meters above sea level. The temperature is $-20^{\circ} \mathrm{C}$ in summer and $-80^{\circ} \mathrm{C}$ in winter.

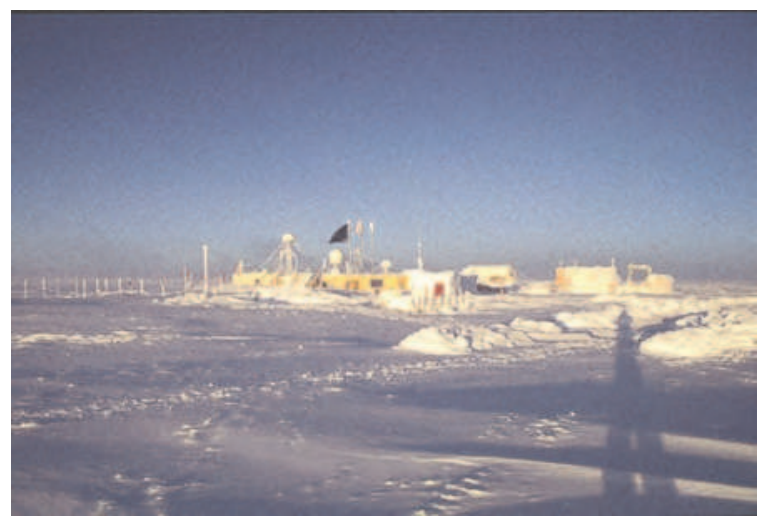

Dome Fuji Base

Day length and Sunlight change is also one particular characteristic in the polar region. At Syowa station on the edge of the Antarctic circle at $569^{\circ}$ degrees, there is night with the midnight sun for one and half months then the sunlight shortens 5 hours every month to the polar night with no daylight. Loss of day light and night causes problems with circadian rhythms leading to insomnia, EEG changes, and autonomic nervous system dysfunction with ECG abnormalities. Excessive change of sunlight hours can also cause emotional instability.

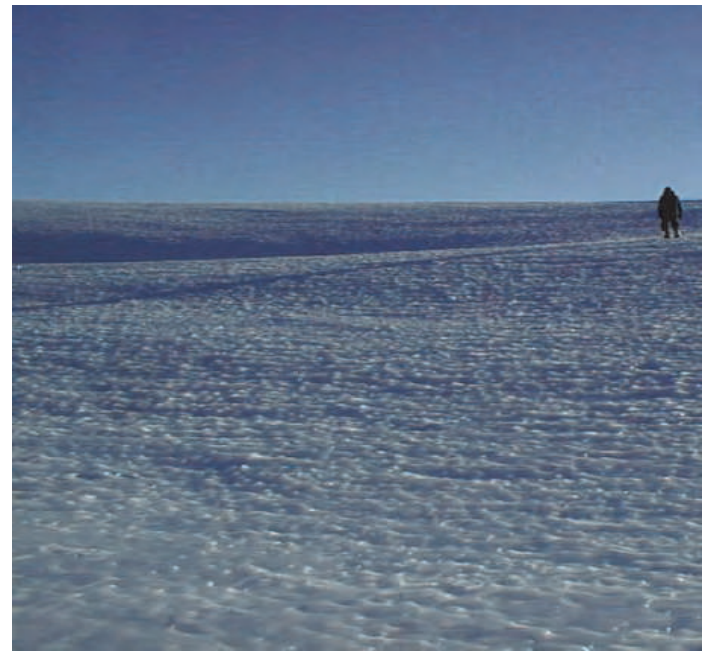


Wintering teams continue nevertheless to grapple with many field operations including high altitude work, diving in the sea and so on.

Each field operation needs several weeks to a few months away from the station with snow tractors and snow mobiles for locomotion and living space. There are crackles on the sea ice as crevasses on the ice sheet wide enough to swallow the mobiles. There are hypobaric effect at high altitude, strong ultraviolet ray under ozone hole, large marine animals can harm divers and so on the risks to health and wellbeing are great. The cold increases with wind chill effects and it is said someone who is immobile with injuries, can only survive for up to an hour or two, though it may take a few days to rescue from station and even this is impossible in stormy weather.

It is impossible not to be exposed to wild nature in any field operations.

The station is $15000 \mathrm{~km}$ distance from Japan. The only means of access is an icebreaker ship which plies between Tokyo and the station once every Austral summer. The ship takes in new winter-over team with the whole commodity to survive for one year and brings the previous team back to Japan. Once the ship leaves, there is no regular transport to the station and in winter it is completely impossible to approach because of huge sheets of oceanic ice and polar darkness.

There are about thirty stations altogether engaged in wintering but none of them is close enough to Syowa station to permit mutual help for each other in an emergency. It may be said that there is no evacuation to or rescue from outside possibly during winter months.

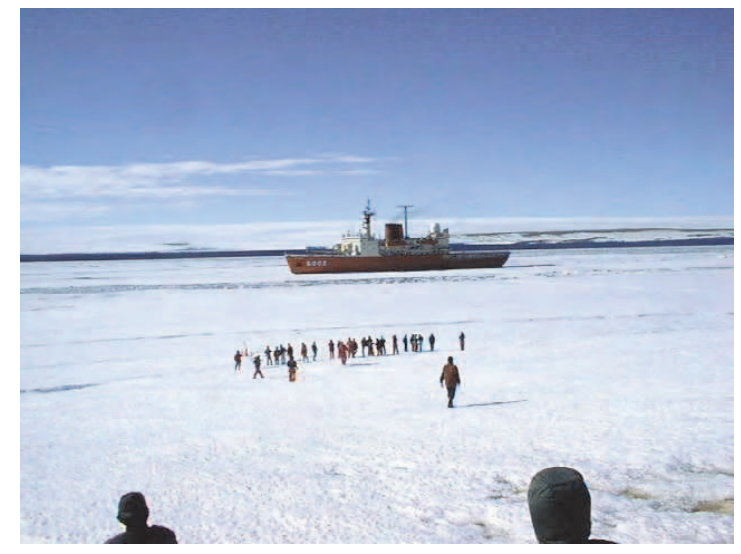

\section{Antarctic doctors must treat every disease with limited medical equipment without paramedical staff}

There are thirty or forty participants who undertake the winter-over every year with two doctors as part of the team. Every member must undergo medical examination to confirm that they are healthy enough to engage in Antarctic activity. Even with this level of screening however, participants need medical consultations four times on average during a single winter.

From 1956 to 2003, a total of 4932 medical consultations have been undertaken. Forty five percent of these are surgical and orthopaedic cases. Injuries, frostbite, sprain, lumbago and 
back pain, burns, fractures etc. are included. Internal disease comprises $23 \%$ of cases consisting of digestive diseases, respiratory ones, head-ache, hypertension, mountain sickness etc.. Dental problems account for $12 \%$ in third place. Others are made up from skin troubles $8 \%$, eye problems $6 \%$, ear, nose and throat $4 \%$, mental problems $2 \%$, and urinary disease. These proportions are preserved in recent survey (shown in the figure) and similar to other nations' stations.

Injuries increase in spring and summer as the frequency of field works increases. Frostbite is observed ordinarily in August, September and October or the coldest season. Another peak of frostbite is shown on April and May, the first period of wintering. People coming from Japan never experience the degree of cold present in Antarctica, so even at the warmest Antarctic season, they are not inured to cold injury.

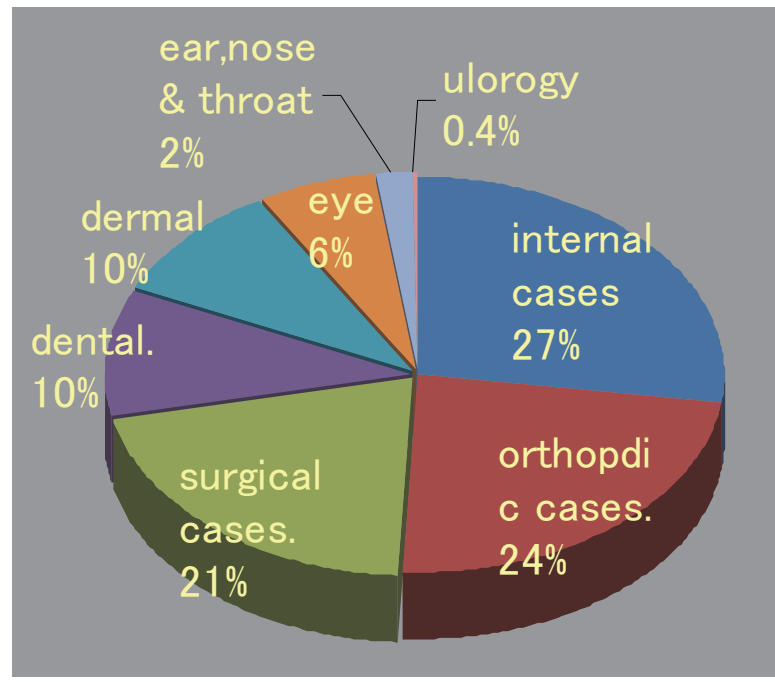

the proportion of 1942 medical consultations from 1997 to 2007

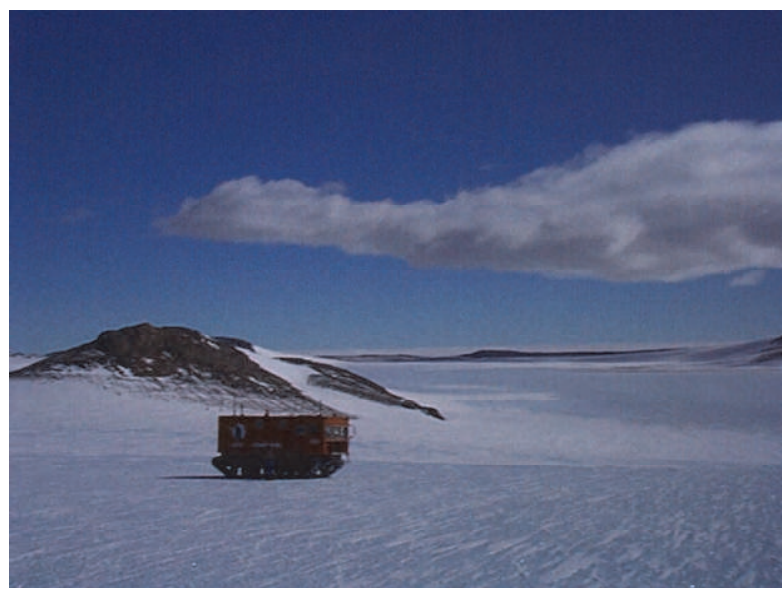


Mountain sickness is experienced with inland operation, especially Dome Fuji trip. Respiratory diseases is rare in winter period in Antarctica where there are no indigenous viruses and immunity to the prevailing one rapidly develops. These increase in summer when the ship with new members arrives station bringing with it a new population of virus. A common problem with teeth is crown dislocations. There is no dentist, so these have to be treated by medical doctors instead.

Some diseases are affected by Antarctic natural conditions such as dryness, strong ultraviolet ray and stiff breeze. For example, photo dermatitis, keratosis, snow blindness, foreign bodies in eyes and pharyngeal spaces are frequently seen. Mental disorders appear to be less of a problem in Japanese stations than in some others where significant depression and other problems have been reported. In Japanese stations the main problems are insomnia and some neuroses.

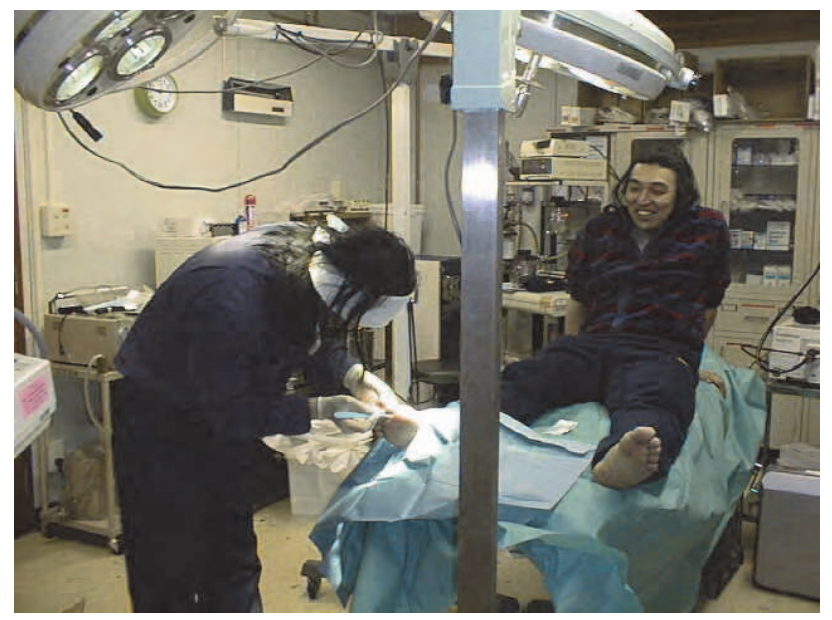

The operation theatre at Syowa Station

There is medical care unit at the station with electrocardiogram, ultrasonic diagnostic equipment, blood laboratory examinations, roentgenogram and fluoroscopy. Medical equipment is available and prepared to perform surgical operations under general anesthesia if needed. Most Antarctic stations have only one medical doctor, but there are two doctors at Syowa station. Usually one goes with field team in summer and the other stays at station. This makes it difficult to perform operations so that only two appendectomies have been done in fifty years.

The possibility of medical evacuation is restricted to summer, but four evacuations have been done. Three of them were with ship for a transcervical femoral fracture caused by falling in a crevasse, a pelvic fracture from a "traffic accident", acute renal failure secondary to prostatic hypertrophy. These three cases were in summer when the ship was near the station to pick up and send the patient to South Africa by ship then to Japan by air. The whole evacuation chain can take almost one month. The fourth case showing arrhythmia at Dome Fuji used air evacuation to shorten the journey time. First a local plane transported the patient to one station providing intercontinental connections. Then the patient was sent to Japan via South Africa. Seven days were needed for the operational evacuation. 
In summary, it is necessary for the Antarctic doctor to manage a whole spectrum of diseases by himself with limited facilities, no medical or paramedical colleagues and no option of outgoing evacuation and incoming rescue for much of the year. The doctor is always a little anxious. Unexpected problems become part of ordinary life, and impossibility of rescue for severe cases creates concern.

It is just such a situation that makes telemedicine indispensable to Antarctic medical operation.

Medical evacuation by air from Dome Fuji toJapan.

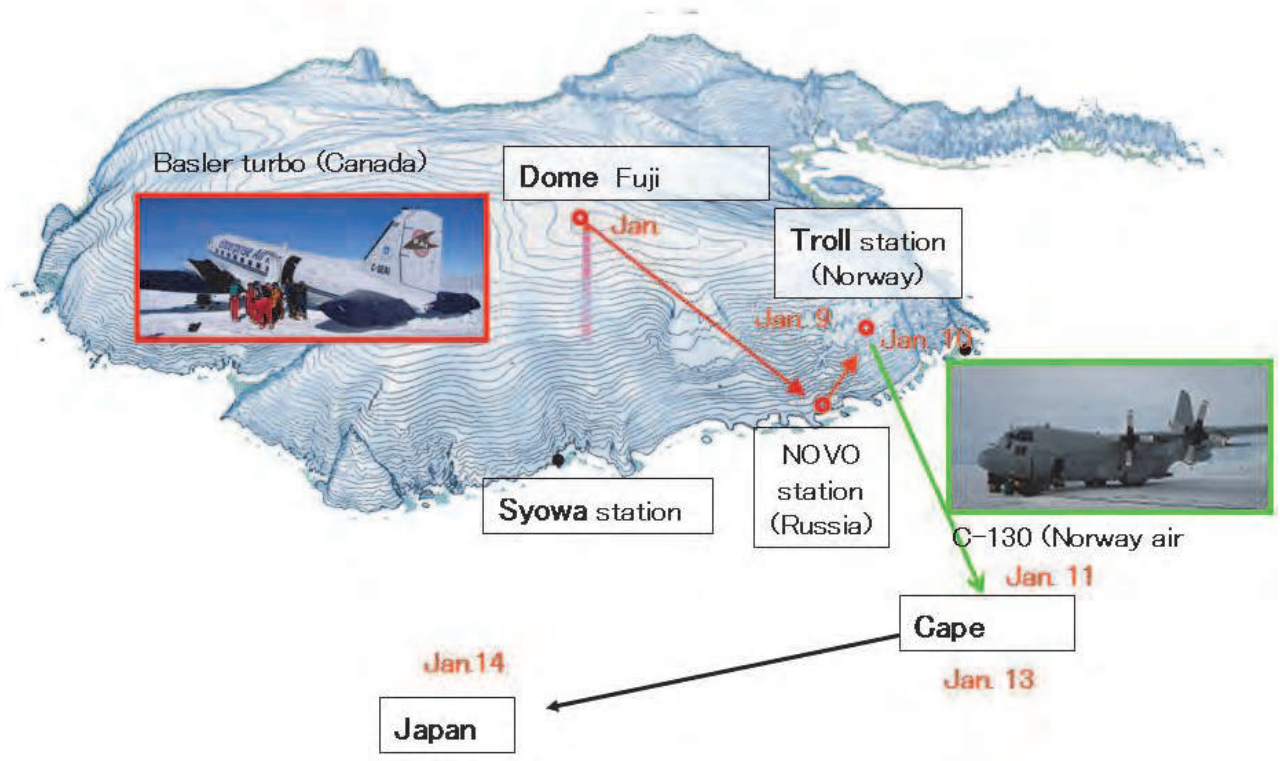

\section{The isolated station needs telemedicine supports}

Though the necessity of medical telecommunication has been recognized for a long time, the practical application stage had to wait for the development of tele-communication engineering.

For two decades after the expedition started in 1956, a radiotelegraph was the only method to communicate with Japan. It was impossible to use the device effectively for medical communications. In 1975, trials of sending electrocardiogram by radio facsimile were made and successfully introduced. Satellite radio-telephone and satellite radio facsimile (1981) was useful to consult directly but without the ability to transmit medical pictures. E-mail by Internationa Mobile Satellite Organization (INMALSAT) making connection every 2 hours and permitting only a maximum $100 \mathrm{~kb} /$ mail.

In 2004, switching to International Telecommunications Satellite organization (INTELSAT) made connection constantly available, and increased the maximum to a $10 \mathrm{Mb} /$ mail making the transmission of still and moving pictures possible.

So INTELSAT makes practical medical telecommunication possible. 

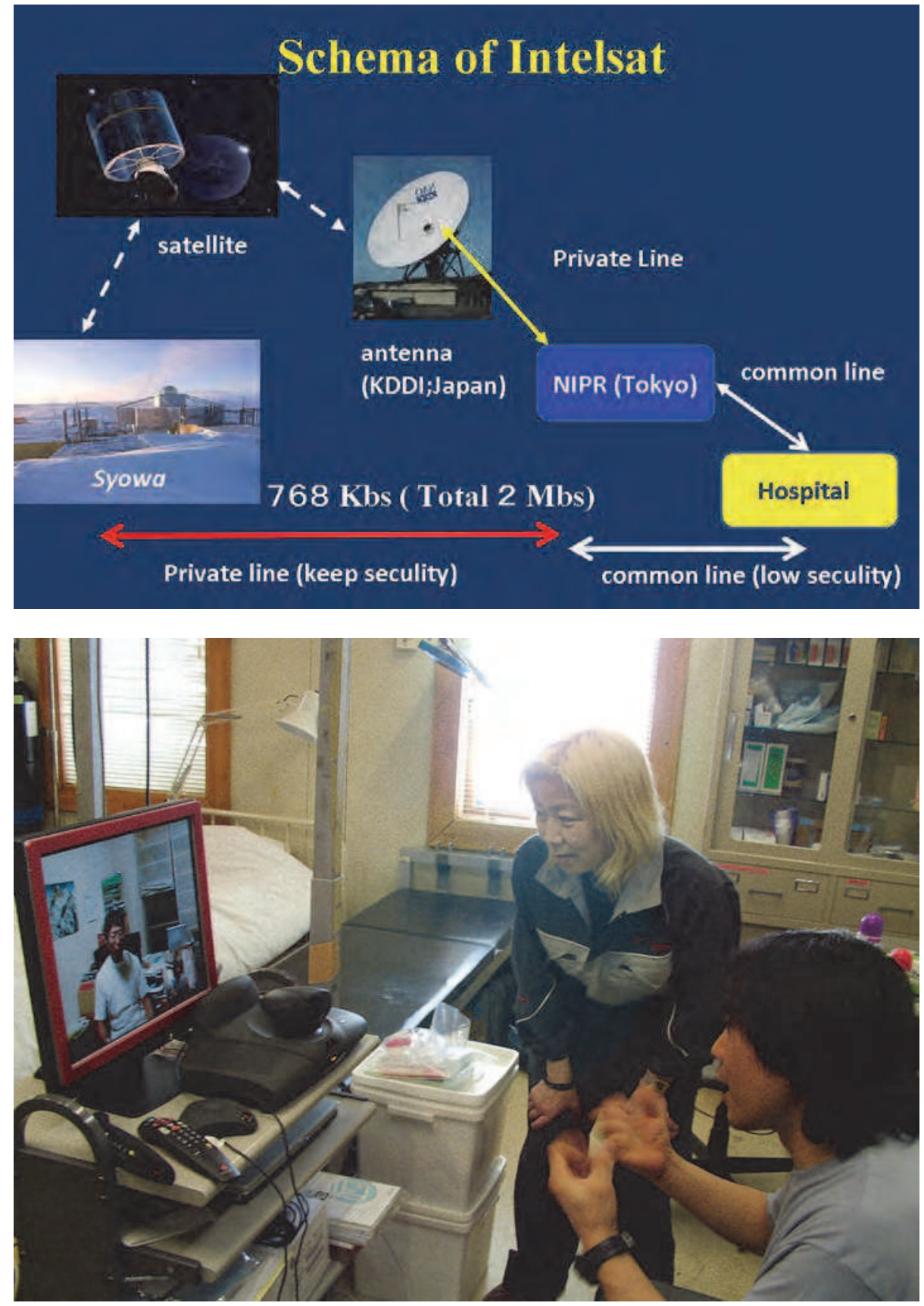

Practice of telecommunication at Syowa station 


\section{The regular scheduled consultation is performed monthly}

The Antarctic doctor (Local doctor) sends some reports about patients' information and images to Japan in advance. A Japanese doctor (home doctor) prepares adequate specialist advice and information responding to this submitted report.

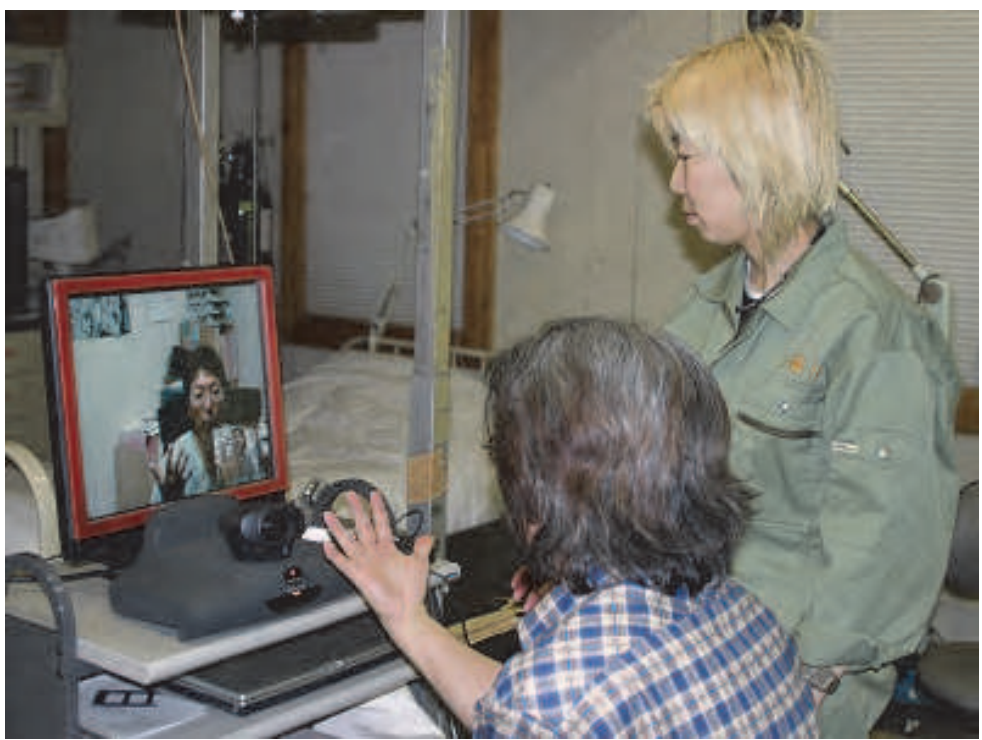

In the tele-communication, home doctor can speak to the patient directly through the TV. The patient also can explain to the doctor satisfactorily without technical terms. Doctor can watch and make an examination as he need in detail.

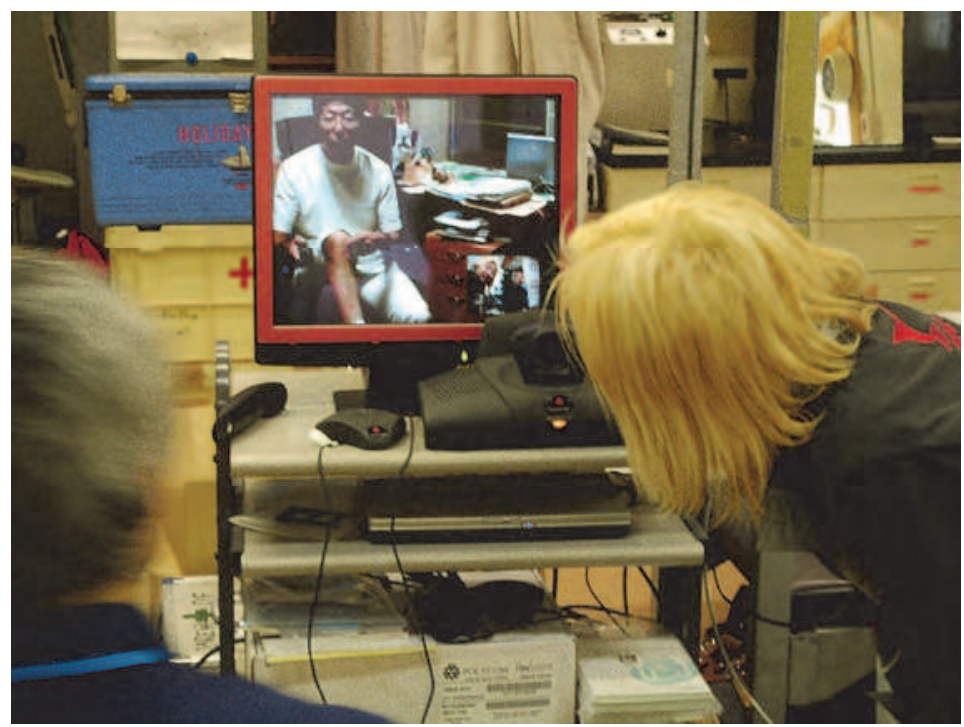


Instead of direct physical examination, home doctor asks the patient and local doctor to do while he watches the video. Thus, the findings through the TV give physical information and so direct interview and substitute physical examination is possible.

It is also possible to counsel on treatment. The home doctor can demonstrate what should be done to the local doctor and he advises and can in real time.

\section{Emergency case}

May 14, 20XX

Syowa Station local time (SLT). Sunrise 10:05 SLT, Sunset 14:31SLT, clear sky, temperature maximum $-12.2^{\circ} \mathrm{C}$, minimum $-20.8^{\circ} \mathrm{C}$.

11:45: (SLT) as 17:40 Japan local time (JLT).

An accident occurred. When one person was moving cargo with a crane, his leg got caught between one cargo and snow tractor.

12:04 SLT: The rescue team with medical doctor arrived on the scene.

12:43 SLT: The patient was admitted to the station. He was shivering and the doctor administered an antibiotic and analgesic agent.

13:25 SLT: The X-ray examination was performed to reveal a fracture of the fibula.

13:30 SLT.(19:30 JLT) First report was sent to National Institute of Polar Research (NIPR) in Japan.

20:00JLT NIPR made the initial call to the collaborating hospital in Japan.

14:30 SLT. Local doctor requested the consultation of specialist

20:30 JLT. Orthopedic surgeons were assembled.

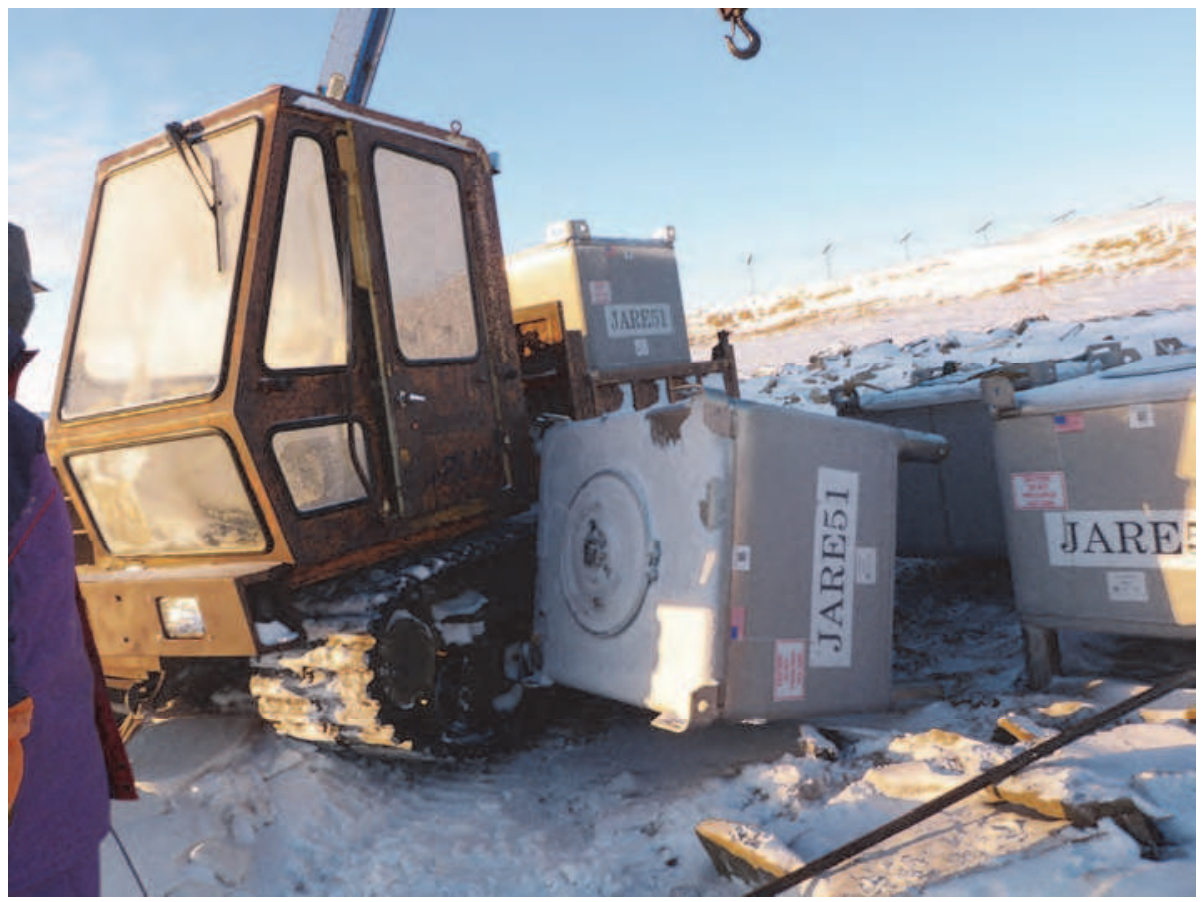




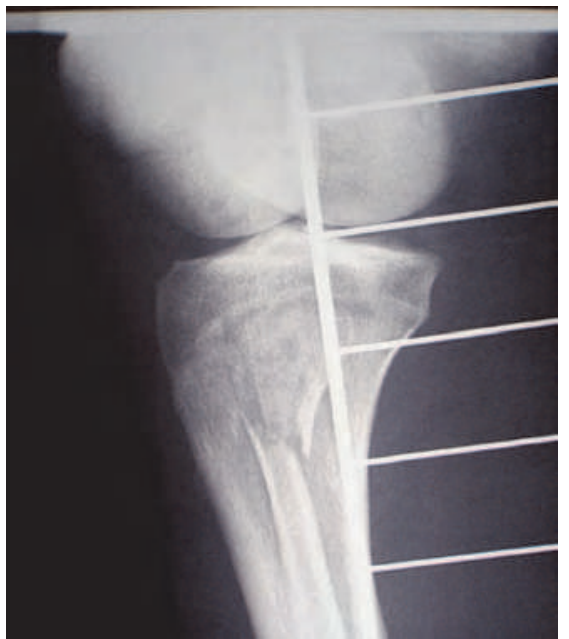

21:15 JLT (15:30 SLT) The consultation was started between the doctor at Syowa station and orthopedic surgeon with telephone and X-ray image sent by e-mail. Diagnosis of fracture was confirmed and therapeutic advice was indicated.

June 4, 20XX

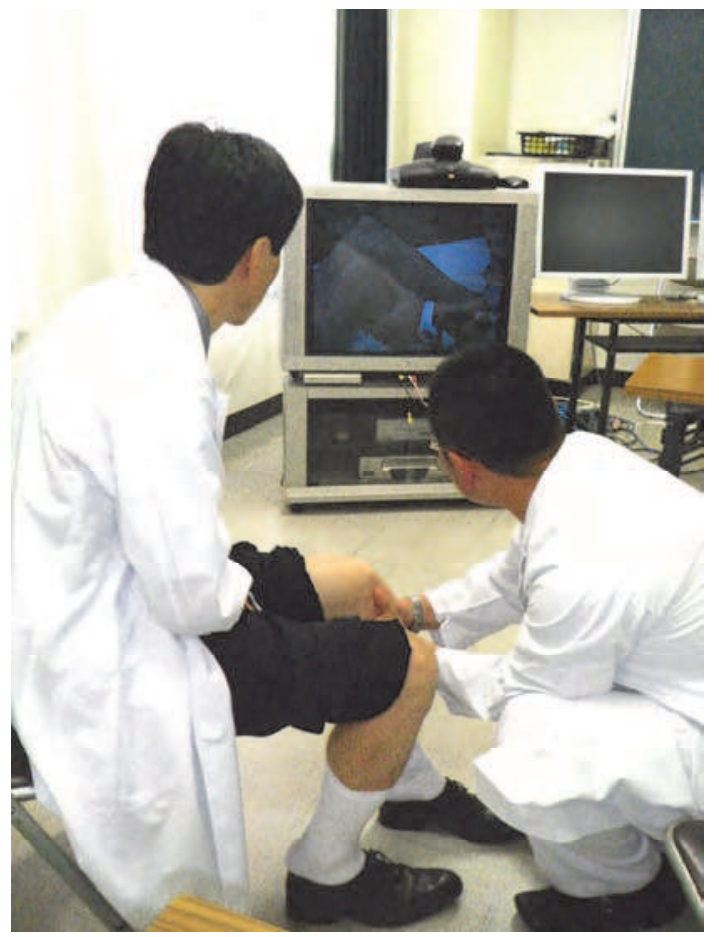

The actual state of telecommunication at hospital in Japan 
Second consultation was performed with TV system. Orthopedic surgeon observed the patient directly and performed physical examination through local doctor. It showed a frontal slippage of knee joint suggesting the ligament injury of knee.

June 18, 20XX

In the third consultation, it was confirmed that the healing of bone was satisfactory. The orthopedic surgeon ordered rehabilitation demonstrating the method practically.

It was ten months after the accident when the patient returned Japan to visit the orthopedic doctor face to face.

\section{The potential of telecommunication in medical operation.}

During one wintering over (February 2004 to January 2005), there were 185 medical consultations. In this wintering team, there were two doctors, one surgeon and one internal physician. The proportion of diseases shows orthopaedic cases were most frequent followed by internal medical cases, surgical cases and skin troubles. Telemedicine consultations were performed for twenty two cases. The TV-system was used 29 times in 17 cases, and still images were sent by e-mail in 5 cases. It is distinctive that telemedicine support is used in many ways for orthopaedic cases and skin in diseases. And also it is interesting that in skin diseases and eye problems, still pictures are preferred to video. Real time communication makes it possible to convey information about mobility without the confusion of verbal descriptions and specific terms showing great advantage in treatment of orthopaedic diseases.

It is notable that the telecommunication system supplies the local doctors with something they are not experts in. Doctors tend to be selected from surgeon, because the surgical injury is frequent and it may be lethal without surgeon. On the other hand, it is difficult for one or two doctors treat all medical cases including those from out of their specialties, one of those areas is the dental problem. Most doctore now are specialists, Antarcticc practice requires the ultimate generalist.

Practical cases of Telemedicine

2005 Feb. 2006 January

\begin{tabular}{|l|c|c|c|c|}
\hline & case & telemedicine & $\begin{array}{c}\text { TV-system } \\
\text { case(times) }\end{array}$ & email \\
\hline total & 185 & 22 & $17(29)$ & 5 \\
\hline Internal med & 42 & 1 & $1(3)$ & \\
\hline Surgery & 35 & 1 & $1(3)$ & \\
\hline Orthope dics & 66 & 13 & $13(20)$ & \\
\hline Ophthalmology & 9 & 1 & & 1 \\
\hline Dermatology & 17 & 4 & $1(1)$ & 3 \\
\hline Otorhinaryngology & 2 & & & \\
\hline Urology & 1 & 1 & $1(2)$ & \\
\hline Dentistry & 13 & 1 & & 1 \\
\hline
\end{tabular}


Some technical problems are still could be improved. It is a basic issue to establish a stable communication. At the first year, only 9 of 24 telecommunication trials were successful. The first five consecutive times failed and thereafter quite often repeated failure to connect voice or picture or both occurred. From the second year, it has made better but there is still a failure a few times each year.

It is necessary to connect directly between Antarctic station and collaborating hospital in an emergency. When the connection becomes required, it has in the past needed NIPR staff to relay, these people are not present in the middle of the night nor on holidays. In 2011, it becomes possible to make connection directly to the hospital without the relay.

There are some concerns about the security of information which is not encrypted or perfectly secure. This is being studied. There is a six-hour time difference between Syowa station and Japan. This can lead to some difficulties in providing arrangements of adequate consulting staff.

A high quality of movie image is desired for diagnosis.

\section{Conclusions for telemedicine}

1. Antarctic Telemedicine support system shows great advantages

2. Real time communication by TV / Video system makes effective medical interview, physical examination and therapeutic management especially in orthopedic cases.

3. High resolution images sent by e-mail are useful to understand the lesions precisely in eyes and skin.

4. Emergency consultation will be effective if adequate consulting staff are prepared and available in spite of time difference.

5 Further improvements in technology will make telemedicine more useful and indispensable.

\section{References}

[1] Grant IC: Telemedocone in the British Antarctic survey. Int J Circumpolar Health. 2004 Dec, 63(4): 356-64

[2] Giichiro Ohno, Takahiro Miyata: Morbidity of wintering-over participants in the First to the Thirty-ninth Japanese Antarctic Research Expeditions: Analysis of 4233 cases. Antarctic Record, Vol. 44, No.1, 1-13, 2000

[3] Giichiro Ohno, Takahiro Miyata: Comparision of medical service systems at Syowa Station with Antarctic stations: Medical staff, mortality and evacuation. Antarctic Record, Vol.44, No.1, 42-50, 2000

[4] Giichiro Ohno, Takahiro Miyata: Diseases due to ultraviolet radiation in Antarcticc wintering personnel: Analysis of geneses, seasonal change and annual variation. Antarctic Record, Vol.44, No.3, 239-248, 2000

[5] Giichiro Ohno, Kentaro Watanabe: We need a broad network of Antarctic medical research---- report of the Japanese workshop on Antarctic Medical Research and Medicine. Circumpolar Hearth Supplements / Proceedings of the $14^{\text {th }}$ international congress on Circumpolar Health 2010(7), 564-567 


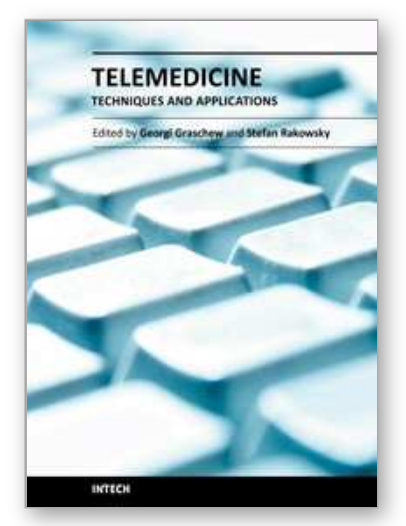

\author{
Telemedicine Techniques and Applications \\ Edited by Prof. Georgi Graschew
}

ISBN 978-953-307-354-5

Hard cover, 514 pages

Publisher InTech

Published online 20, June, 2011

Published in print edition June, 2011

Telemedicine is a rapidly evolving field as new technologies are implemented for example for the development of wireless sensors, quality data transmission. Using the Internet applications such as counseling, clinical consultation support and home care monitoring and management are more and more realized, which improves access to high level medical care in underserved areas. The 23 chapters of this book present manifold examples of telemedicine treating both theoretical and practical foundations and application scenarios.

\title{
How to reference
}

In order to correctly reference this scholarly work, feel free to copy and paste the following:

Giichiro Ohno (2011). Practical Results of Telemedicine System Between Antarctic Station and Japan, Telemedicine Techniques and Applications, Prof. Georgi Graschew (Ed.), ISBN: 978-953-307-354-5, InTech, Available from: http://www.intechopen.com/books/telemedicine-techniques-and-applications/practical-resultsof-telemedicine-system-between-antarctic-station-and-japan

\section{INTECH}

open science | open minds

\section{InTech Europe}

University Campus STeP Ri

Slavka Krautzeka 83/A

51000 Rijeka, Croatia

Phone: +385 (51) 770447

Fax: +385 (51) 686166

www.intechopen.com

\section{InTech China}

Unit 405, Office Block, Hotel Equatorial Shanghai

No.65, Yan An Road (West), Shanghai, 200040, China

中国上海市延安西路65号上海国际贵都大饭店办公楼 405 单元

Phone: +86-21-62489820

Fax: +86-21-62489821 
(C) 2011 The Author(s). Licensee IntechOpen. This chapter is distributed under the terms of the Creative Commons Attribution-NonCommercialShareAlike-3.0 License, which permits use, distribution and reproduction for non-commercial purposes, provided the original is properly cited and derivative works building on this content are distributed under the same license. 